\title{
DISTRIBUSI, PELEPASAN, DAN PERUBAHAN FONEM [R] DALAM KOMUNIKASI ANAK USIA 3 TAHUN
}

\section{DISTRIBUTION, RELEASING AND 3 YEARS OLD CHILDREN CHANGING [R] PHONEME}

\author{
Sakrim* \\ Pendidikan Bahasa dan Sastra Indonesia, STKIP PGRI Bangkalan, Indonesia \\ sakrim@stkippgri-bkl.ac.id \\ *penulis korespondensi
}

\begin{tabular}{ll}
\hline Info Artikel & ABSTRAK \\
\hline Sejarah artikel: & Alat ucap sangat mendominasi terhadap ketepatan dalam mendistribusikan \\
Diterima: & dan pelepasan fonem. Ketika alat ucap tidak sempurna maka akan memberi \\
6 Juni 2020 & efek bagi lingual. Distribusi dan pelepasan fonem tidak akan semestinya \\
Direvisi: & tepat dan benar jika alat ucap sebagai elemen pendukung tidak sempurna. \\
19 Juni 2020 & Alat ucap yang terdepan membantu untuk merealisasikan keluarnya bunyi \\
Disetujui: & fonem yang diharapkan khususnya fonem [R], hal ini sering terjadi pada \\
14 Juli 2020 & anak usia dini. Anak usia 3 tahun bisa mendistribusikan fonem-fonem yang \\
& ringan untuk dikomunikasikan. Anak usia 3 tahun alat ucapnya tidak \\
Kata kunci: & sempurna seperti orang dewasa. Ketidaksempurnaan alat bicara sangat \\
Pemerolehan Bahasa,, & mempengaruhi terhadap bicara anak khususnya untuk mendistribusikan \\
anak usia 3 & fonem-fonem yang sulit seperti fonem [R], [S], dan [F]. Problem seperti itu \\
tahun, distribusi & terjadi bukan hanya di pedesaan, di daerah kota masih banyak temuan dalam \\
& berkomunikasi anak tidak bisa menggunakan fonem [R]. Pengumpulan data \\
& dalam penelitian ini yaitu, metode simak, rekam, dan catat. Berdasarkan \\
& hasil penelitian yang dilakukan ditemukan beberapa data kesalahan \\
& pelepasan bunyi fonem [R] di awal kata, kesalahan pelepasan bunyi fonem \\
& [R] di tengah kata, dan kesalahan pelepasan bunyi fonem [R] di akhir kata.
\end{tabular}

\begin{tabular}{ll}
\hline Article Info & ABSTRACT \\
\hline Article history: & The speech instrument dominates the accuracy in distributing and releasing \\
Received: & phonemes. When the utterance is not perfect, it will have an effect on the \\
6 June 2020 & lingual. The distribution and releasing phonemes will not be appropriate and \\
Revised: & correc,t if the speech device, as supporting element, is not perfect. The the \\
19 June 2020 & front speech device helps to realize the expected phoneme sounds, \\
Accepted: & $\begin{array}{l}\text { especially phonemes [R], this often occurs in early childhood. 3 years old } \\
\text { children can distribute light phonemes to be communicated. A 3-year-old }\end{array}$ \\
14 July 2020 & child speech is not as perfect as an adult. Speech device imperfections are \\
Keyword: & very influential on children's speech, especially to distribute difficult \\
Language acquisition, & phonemes such as [R], [S], and [F] phonemes. This problem does not occur \\
3-year-old child, & only in rural areas, in urban areas there are still many findings in children \\
distribution & cannot communicate using phonemes [R]. Data collection in this research is \\
& analytic method, recording, and taking note. Based on the results of \\
& conducting research found that some data errors in the release of phonemes \\
& [R] at the beginning of words, errors in releasing phonemes [R] in the middle \\
& of words, and errors in releasing phonemes [R] at the end of words.
\end{tabular}




\section{PENDAHULUAN}

Beberapa anak usia 3 tahun cara berbicara belum sempurna, apalagi berbicara dengan menggunakan fonemfonem yang krusial seperti fonem [R], $[\mathrm{S}]$, dan $[\mathrm{F}]$. Anak usia 3 tahun bisa mendistribusikan fonem-fonem yang ringan untuk dikomunikasikan. Problem seperti itu terjadi bukan hanya di pedesaan, di daerah kota masih ada temuan dalam berkomunikasi anak tidak bisa menggunakan fonem [R].

Dalam hal ini Jobson meramalkan urutan pemerolehan bunyi, berdasarkan data yang dikumpulkan dari para pakar seperti Clark dan Clark, Ervin-Tripp, dan Foss dan Hakes. Data yang dikumpulkan itu menunjukkan bahawa kanak-kanak lebih dahulu membunyikan [b], [p], [d], dan [t] dari pada bunyi [f], dan [s]. Oleh karena itu, sering terjadi [f] ditukar dengan [p] seperti kanak-kanak mengucapkan (pis) untuk <frish $>$; atau bunyi [s] ditukar dengan [t] seperti kata <suit> yang diucapkan menjadi [tut] (Chaer, 2015:204)

Menjadi poin penting dalam penelitian ini setelah praobservasi dilakukan yang tidak bisa mendistribusikan fonem [R] dalam kata, frasa, klausa, dan sampai pada kalimat bukan hanya anak usia 3 tahun. Anak usia 5 tahun pun masih ada yang belum bisa mendistribusikan bunyi fonem [R]. Proses fonasi harus tepat pada penggunaan, ketepatan proses fonasi harus dikaji secara intans. Menurut (Chaer 207:106) terjadinya bunyi bahasa pada umumnya dimulai dengan proses fonasi pemompaan udara keluar dari paru-paru melalui pangkal tenggorokan ke pangkal tenggorokan, yang di dalamnya terdapat pita suara. Supaya udara bisa terus keluar, pita suara itu harus berada dalam posisi terbuka. Setelah melalui pita suara, yang merupakan jalan satusatunya untuk bisa keluar, entah melalui rongga mulut atau rongga hidung, udara tadi diteruskan ke udara bebas. Kalau udara yang dari paru-paru itu keluar tanpa hambatan apa-apa, maka tidak akan mendengar bunyi apaapa, selain bunyi napas.

Alat ucap sangat mendominasi
terhadap ketepatan dalam mendistribusikan dan pelepasan fonem krusial. Distribusi dan pelepasan fonem tidak akan semestinya tepat dan benar jika alat ucap sebagai elemen pendukung tidak sempurna. Alat ucap yang terdepan membantu untuk merealisasikan keluarnya bunyi fonem yang diharapkan sesuai forsi khususnya fonem [R], tentunya ada juga perangkat lain sebagai pendorong terbentuknya distribusi dan pelepasan fonem.

Tentunya banyak hal yang menjadi faktor dalam pendistribusian dan pelepasan bunyi fonem [R] dalam berbicara. Orang tua sangat besar perannya terhadap proses distribusi fonem [R] pada pembicaraan anak. Menurut (Cher 2013:89). "yang dimaksud dengan distribusi fonem adalah letak atau beradanya sebuah fonem di dalam satu satuan ujaran, fonem diproses oleh alat ucap secara sempurna.

Persoalan distribusi fonem menjadi hal urgent dalam komunikasi. Lingkungan atau tempat tinggal anak sangat menentukan kecakapan dalam berbicara. Sebelum anak berbicara, anak akan meniru pembicaraan orang terdekat. Dalam lingkungan keluarga, anak akan berbicara dengan orang tua, saudara, tetangga, dan teman sebayanya. Dalam lingkungan masyarakat anak akan berbicara dengan masyarakat. Dalam lingkungan pendidikan anak akan berbicara dengan 
teman sebaya, guru, dan semua elemen dalam pendidikan.

Beberapa bidang ilmu yang harus dimiliki oleh seseorang dalam berbicara adalah fonologi dan morfologi. Fonologi ilmu yang mengkaji tentang pembendaharaan bunyi bahasa yang diproduksi oleh alat ucap manusia. Fonologi mengkaji alatalat ucap manusia dan produksi terhadap huruf vokal dan konsonan. Morfologi ilmu yang mengkaji tentang pembentukan kata atau afiksasi. Afiks dibagi menjadi empat yaitu, prefiks, infiks, sufik, dan konfiks.

PAUD Al-Usmaniyah berada di Bandang Laok Kecamatan Kokop. Mayoritas aktivitas orang tua peserta didik petani, jika tidak bertani mereka berangkat ke luar negara seperti Arab Saudi, Malaysia, dan Kalimantan. Peserta didik tinggal bersama kakek, nenek, dan saudara kandungnya. Bahasa yang didistribusikan saat berbicara bahasa Madura dan merupakan bahasa ibu.

Posisi guru saat mengajar di sekolah tidak $100 \%$ akan membantu problem ini. Waktu guru di sekolah tidak melebihi waktu anak bersama orang tua. Keduanya harus saling support, dan berkolaborasi agar semuanya menjadi baik. Guru di sekolah mengajar dan mendidik dari segala macam keilmuan, di rumah orang tua mengingatkan, memotivasi, dan mengoreksi kegiatan anak saat di sekolah.

Masyarakat Bandang Laok Kecamatan Kokop bervariasi ditinjau tingkat pendidikan, ekonomi, dan sosialnya. Tahun 70-an masih banyak masyarakat Bandang Laok yang belum lulus SD, SMP, SMA, dan S-1 atau sederajat. Berangkat dari background pendidikan masyarakat Bandang Laok Kecamatan Kokop sangat jelas bahwa yang dihadapi peserta didik, lingkungan PAUD Al-Usmaniyah krisis dari segala aspek akademi formal.

Berangkat dari latar belakang ini, sudah sepatutnya penelitian ini diangkat sebagai pemecahan masalah distribusi bunyi fonem [R] pada anak usia 3 tahun di PAUD Al-Usmaniyah. Harapannya setelah penelitian ini sudah berhasil bisa menjadi kebiasaan bagi masyarakat khususnya pada anak usia 3 tahun di PAUD Al-Usmaniyah Desa Bandang Laok Kecamatan Kokop. Selain itu juga sebagai tambahan pengetahuan dalam berbicara.

Berdasarkan hal di atas, penelitian ini membahas tentang Distribusi, Pelepasan dan Perubahan Fonem [R] dalam Komunikasi Anak Usia 3 Tahun di PAUD Al-Usmaniyah di desa Bandang Laok Kecamatan Kokop Kabupaten Bangkalan Tahun Ajaran 2020.

\section{METODE}

Penelitian ini merupakan penelitian deskriptif kualitatif, (1) Bagaimana distribusi bunyi $[R]$ dalam komunikasi anak usia 3 tahun di PAUD Al-Usmaniyah di desa Bandang Laok Kecamatan Kokop? (2) Bagaimana pelepasan bunyi $[\mathrm{R}]$ dalam komunikasi anak usia 3 tahun di PAUD AlUsmaniyah di Desa Bandang Laok Kecamatan Kokop?

Subjek penelitian ini siswa PAUD, 12 siswa dalam satu kelas. Data penelitian ini berupa kata, frasa, klausa, dan kalimat. Pengumpulan data akan dilakukan sendiri oleh peneliti dengan menggunakan metode simak, rekam, dan catat. Metode simak dilakukan dengan cara menyimak penggunaan bahasa subjek peneliti dengan cara teknik sadap. Data yang berbentuk kata, frasa, dan kalimat dengan bunyi [R] akan ditranskripsi fonetiskan oleh 
peneliti agar bisa diketahui proses distribusinya.

\section{HASIL DAN PEMBAHASAN}

Bila mendengar suara orang berbicara entah berpidato atau bercakap-cakap, maka akan dengar runtunan bunyi-bunyi bahasa yang terus menerus, kadang-kadang terdengar suara menaik dan menurun, kadang-kadang terdengar hentian sejenak dan hentian agak lama, kadangkadang terdengar pula suara panjang dan suara biasa, dan sebagainya. Runtunan bunyi bahasa ini dapat dianalisis atau disegmentasikan berdasarkan tingkat-tingkat kesatuannya (Chaer Abdul: 2009).

Penelitian ini akan memberi gambaran kajian fonologi yang disampaikan oleh para ahli bahasa di atas. Gambaran itu mengacu pada distribusi bunyi bahasa yang disampaikan oleh anak usia 3 tahun. Hasil penelitian ini diuraikan menjadi dua bagian, yaitu (1) distribusi bunyi [R] dalam komunikasi anak usia 3 tahun di PAUD Al-Usmaniyah Desa Bandang Laok (2) pelepasan bunyi [R] dalam komonikasi anak usia 3 tahun di PAUD Al-Usmaniyah Desa Bandang Laok, di bawah ini data dan analisis bunya [R].

\section{Distribusi Bunyi [R]}

Bunyi $[R]$ yang didistribusikan anak usia 3 tahun di PAUD AlUsmaniyah Bandang Laok Kecamatan Kokop pada awal kata.

\section{Rambut saya hitam. (R1/PDR/D1)}

Komunikasi pada data di atas merupakan komunikasi antara guru dan siswa pada anak usia 3 tahun di PAUD Al-Usmaniyah Bandang Laok
Kecamatan Kokop. Pada komunikasi antara siswa dan guru di atas terdapat distribusi bunyi [R] pada kata [Rambut] yang didistribusikan oleh siswa. Pada kata rambut merupakan jawaban siswa PAUD Al-Usmaniyah Bandang Laok saat ditanya oleh gurunya. Pada pelafalan pendistribusian bunyi [R] oleh anak usia 3 tahun di PAUD AlUsmaniyah Bandang Laok tidak dilafalkan rambut tetapi dengan kata lambut, bunyi ra berganti menjadi $l a$.

\section{Rian tidak masuk bu! (R1/PDR/D2)}

Komunikasi pada data kedua di atas merupakan komunikasi antara guru dan siswa pada anak usia 3 tahun di PAUD Al-Usmaniyah Bandang Laok. Pada komunikasi antara siswa dan guru di atas terdapat distribusi bunyi [R]) pada kata [Rian] yang didistribusikan oleh siswa. Pada kata rian merupakan jawaban siswa PAUD Al-Usmaniyah Bandang Laok saat ditanya oleh gurunya. Pada pelafalan pendistribusian bunyi [R] oleh anak usia 3 tahun di PAUD Al-Usmaniyah Bandang Laok tidak dilafalkan Rian tetapi dengan kata lian, bunyi ri berganti menjadi $l i$.

3. Raisa ikut ibunya ke sawah. (R1/PBR/D3).

Komunikasi pada data ketiga di atas merupakan komunikasi antara guru dan siswa pada anak usia 3 tahun di PAUD Al-Usmaniyah Bandang Laok. Pada komunikasi antara siswa dan guru di atas terdapat distribusi bunyi [R] pada kata [Raisa] yang didistribusikan oleh siswa. Pada kata raisa merupakan jawaban siswa PAUD Al-Usmaniyah Bandang Laok saat ditanya oleh gurunya "kemana Raisa tidak masuk"? 
Pada pelafalan pendistribusian bunyi [R] oleh anak usia 3 tahun di PAUD AlUsmaniyah Bandang Laok tidak dilafalkan raisa tetapi dengan kata laisa, bunyi $r a$ berganti menjadi la .

Distribusi Bunyi [R] di Tengah Kata Distribusi pelafalan bunyi [R] yang ditemukan di tengah kata.

4. Hore...Perjuanganku berhasil. (R1/PBR/D4)

Komunikasi pada data keempat di atas merupakan komunikasi siswa usia 3 tahun di PAUD Al-Usmaniyah Bandang Laok saat mengerjakan tugas. Pada komunikasi siswa di atas terdapat distribusi bunyi $[\mathrm{R}]$ pada kata hore, per, dan ber yang didistribusikan oleh siswa. Pada kata Hore, per, dan ber merupakan jawaban siswa PAUD AlUsmaniyah Bandang Laok saat mengerjakan tugas dan dia berhasil mengerjakan dengan cepat dan benar. Pada pelafalan pendistribusian bunyi [R] oleh anak usia 3 tahun di PAUD AlUsmaniyah Bandang Laok tidak dilafalkan Hore... tetapi dengan kata Hole, bunyi re berganti menjadi le, bunyi [R] berganti [i] pada kata peijuanganku bunyi [R] berganti [i] pada kata berhasil.

5. Mari menyapu semua! (R1/PBR/D5)

Komunikasi pada data kelima di atas merupakan komunikasi siswa usia 3 tahun di PAUD Al-Usmaniyah Bandang Laok saat piket kelas. Pada komunikasi siswa di atas terdapat distribusi bunyi [R] pada kata [Mari] yang didistribusikan oleh siswa. Pada kata Mari merupakan ajakan siswa terhadap teman piketnya di dalam kelas PAUD Al-Usmaniyah Bandang Laok.
Pada pelafalan pendistribusian bunyi [R] oleh anak usia 3 tahun di TK AlUsmaniyah Bandang Laok tidak dilafalkan Mari... tetapi dengan kata Mali, bunyi ri berganti menjadi $l i$.

\section{Perutku mules ibu! (R1/PBR/D6)}

Komunikasi pada data keenam di atas merupakan komunikasi antara guru dan siswa pada anak usia 3 tahun di PAUD Al-Usmaniyah Bandang Laok. Pada komunikasi antara siswa dan guru di atas terdapat distribusi bunyi [R] pada kata [Rian] yang didistribusikan oleh siswa. Pada kata perut merupakan jawaban siswa Al-Usmaniyah Bandang Laok saat ditanya oleh gurunya "Kenapa kamu tidak menulis? Pada pelafalan pendistribusian bunyi [R] oleh anak usia 3 tahun di PAUD AlUsmaniyah Bandang Laok tidak dilafalkan Perut tetapi dengan kata Pelut, bunyi rut berganti menjadi lut.

\section{Distribusi Bunyi [R] di Akhir Kata}

Berikut ini dapat distribusi bunyi [R] di akhir kata.

\section{Manjur jamunya bu! (R1/PBR/D7)}

Komunikasi pada data ketujuh di atas merupakan komounikasi antara guru dan siswa pada anak usia 3 tahun di PAUD Al-Usmaniyah Bandang Laok. Pada komunikasi antara siswa dan guru di atas terdapat distribusi bunyi [R] pada kata [Manjur] yang didistribusikan oleh siswa. Pada kata Manjur merupakan jawaban siswa PAUD Al-Usmaniyah Bandang Laok saat ditanya oleh gurunya "Kenapa kamu kelihatannya sehat? Pada palafalan pendistribusian bunyi [R] oleh anak usia 3 tahun di PAUD Al- 
Usmaniyah Bandang Laok tidak dilafalkan Manjur tetapi dengan kata Manjul, bunyi jur berganti menjadi jul.

\section{Syukur ya Allah! (R1/PBR/D8)}

Komunikasi pada data kedelapan di atas merupakan komunikasi antara guru dan siswa pada anak usia 3 tahun di PAUD Al-Usmaniyah Bandang Laok. Pada komunikasi antara siswa dan guru di atas terdapat distribusi bunyi [R] pada kata [Syukur] yang didistribusikan oleh siswa. Pada kata Syukur merupakan ungkapan berterima kasih atas nikmat setelah makan siswa PAUD Al-Usmaniyah Bandang Laok. Pada pelafalan pendistribusian bunyi [R] oleh anak usia 3 tahun di PAUD Al-Usmaniyah Bandang Laok tidak dilafalkan Syukur tetapi dengan kata Syukul, bunyi kur berganti menjadi $k u l$.

\section{Penyebab Bunyi [R]}

Setelah dilakukan wawancara terhadap guru dan orang tua siswa di lingkungan Al-Usmaniyah Bandang Laok terdapat beberapa faktor. Pertama dari beberapa siswa yang menjadi objek penelitian di PAUD Al-Usmaniyah Bandang Laok Kecamatan Kokop pelafalan pendistribusian bunyi huruf $[R]$ tidak sesuai dengan bunyi aslinya karena kurangnya latihan dari orang tua terhadap anaknya dalam melafalkan bunyi huruf [R]. Kedua ada sebagian anak yang sudah dilatih oleh orang tua atau keluarga di rumah, tetapi tetap saja tidak bisa. Yang ketiga ada sebagian siswa yang memang bawaan sejak lahir.

\section{Distribusi Bunyi Bahasa}

Berdasarkan data penelitian di atas sangat jelas bahwa bunyi bahasa sangat dipengaruhi oleh alat ucap manusia. Hal ini Muslich, Mansur (2010:3) menjelaskan fonetik adalah bunyi-bunyi ujar dipandang sebagai media bahasa semata, seperti benda atau zat. Dengan demikian, bunyibunyi dianggap sebagai bahan mentah, bagaikan batu, pasir, semen sebagai bahan mentah bangunan rumah. Secara umum fonetik bisa dijelaskan sebagai cabang fonologi yang mengkaji bunyibunyi bahasa tanpa memperhatikan statusnya, apakah bunyi-bunyi bahasa itu dapat membedakan makna (kata) atau tidak.

Pelepasan dan distribusi bunyi bahasa yang dilafalkan oleh siswa PAUD Al-Usmaniyah Desa Bandang Laok menunjukkan bahwa ada gangguan atau ketidaksempurnaan pada alat ucap siswa tersebut. Sejalan dengan pendapat (Yulia Eka Salnita dkk, 2019:141) di dalam penelitiannya bidang fonologis terdapat bunyi bahasa yang mengalami perubahan fonem. Ada satuan fonem yang lesap seperti pada kata sepeda dibaca cepeda, luar dibaca lual, fonem /s/ berubah menjadi fonem /c/. Selain itu, untuk fonem /r/ berubah menjadi fonem /1/. Hal ini terjadi karena anak berusia 3 tahun belum bisa mengujarkan fonem /r/ dan /s/ dangan benar.

Senada dengan pendapat (Sri Kurnia Hastuti Sebayang, 2018:112) dijabarkan hasil penelitiannya dari segi fonologi, Siti yang berumur 3 tahun sudah mampu untuk berujar. Hal ini bisa diperiksa secara seksama. Meskipun ada beberapa huruf yang ia belum mampu untuk mengucapkan dengan baik. Contoh pada fonem /s/ ,/m/, /k/, /l/ dan lain-lain. Sebenarnya pada pola tertentu Siti bisa mengucapkan fonem mungkin pada fonem yang mudah diucapkan tetapi, pada pola kata yang sulit, Siti tidak bisa mengucapkan fonem dengan sempurna. 
Misalnya pada kata (sion) ia tidak bisa mengucapkan fonem /s/ mungkin fonem /s/ katagori fonem yang sulit untuk diucapkan sehingga ia mengganti dengan fonem /y/ (yion). Hal yang sama diucapkan oleh ia, kata (tarian) diucapkan (cerian) fonem /t/ diganti dengan fonem /c/. Hal ini juga ditegaskan oleh Chaer Abdul (2013:89) yang dimaksud dengan distribusi fonem adalah letak atau beradanya sebuah fonem di dalam satu satuan ujaran, yang kita sebuat kata atau morfem.

\section{Alat Ucap}

Dalam fonetik artikulatoris hal pertama yang harus dibicarakan adalah alat ucap manusia untuk menghasilkan bunyi bahasa. Bunyi-bunyi yang terjadi pada alat-alat ucap itu biasanya diberi nama sesuai dengan nama alat ucap itu. Namun, tidak biasa disebut "bunyi gigi" atau "bunyi bibir" melainkan bunyi dental dan bunyi labial, yakni istilah berupa bentuk ajektif dari bahasa lainnya.

Selanjutnya, sesuai dengan bunyi bahasa itu dihasilkan, maka harus digabungkan istilah dari dua nama alat ucap itu. Misalnya, bunyi apikodental yaitu gabungan antara ujung lidah dengan gigi atas, labiodental yaitu gabungan antara bibir bawah dengan gigi atas, dan laminopalatal yaitu gabungan antara daun lidah dengan langit-langit keras. Fungsi utama lain yang bersifat fisiologis misalnya paruparu untuk bernafas, lidah untuk mencecap dan gigi untuk mengunyah. Alat-alat itu secara linguistik digunakan untuk menghasilkan bunyibunyi bahasa sewaktu berujar.

\section{Proses Fonasi}

Ada beberapa hal yang terlibat dalam proses bunyi bahasa yaitu, alat ucap yang dimiliki sesorang, beberapa alat ucap yang dimiliki seseorang ada yang menimbulkan getaran. Terjadinya getaran melalui udara yang dipompa oleh paru-paru dan keluar lewat rongga mulut atau rongga tenggorokan. Hasil yang dicapai dalam proses fonasi adalah gabungan bunyi vokal dan konsonan secara sistematis. Yang dimaksud gabungan bunyi vokal dan konsonan adalah bentuk bahasa yang utuh bermakna seperti kata, frasa, klausa, kalimat dan sampai wacana.

\section{Perubahan Fonem}

Ucapan sebuah fonem dapat berbeda-beda sebab sangat bergantung pada lingkungannya, atau pada fonemfonem lain yang berada di sekitarnya, (Chaer Abdul 207:132).

Dari hasil penelitian ini sangat banyak temuan perubahan bunyi fonem yang dilafalkan oleh siswa PAUD AlUsmaniyah Desa Bandang Laok misalnya pada data 1 , data 2 , dan sampai pada data terakhir berbagai macam temuan pelepasan dan distribusi fonem yang tidak sempurna. Bunyibunyi yang didistribusikan oleh siswa yaitu bunyi vokal dan konsonan.

\section{Klasifikasi Bunyi}

Pada umumnya bunyi bahasa dibedakan atas vokal dan konsonan. Jadi, beda terjadinya bunyi vokal dan konsonan adalah arus udara dalam pembentukan bunyi vokal setelah melewati pita suara, tidak mendapat hambatan apa-apa, sedangkan dalam pembentukan bunyi konsonan arus udara itu masih mendapat hambatan atau gangguan. Bunyi konsonan ada yang bersuara ada yang tidak, yang bersuara terjadi apabila pita suara terbuka sedikit dan yang tidak bersuara apabila pita suara terbuka agak lebar. Bunyi vokal, semuanya adalah 
bersuara, sebab dihasilkan dengan pita suara terbuka sedikit.

\section{Tulisan Fonetik}

Tulisan fonetik yang dibuat untuk keperluan studi fonetik, sesungguhnya dibuat berdasarkan huruf-huruf dari aksara latin, yang ditambah dengan sejumlah tanda diakritik dan sejumlah modifikasi terhadap huruf latin itu. Kalau dalam tulisan fonetik, setiap bunyi baik yang segmental maupun yang suprasegmental, dilambangkan secara akurat artinya setiap bunyi mempunyai lambang-lambangnya sendiri, meskipun perbedaannya hanya sedikit, tetapi dalam tulisan fonemik hanya perbedaan bunyi yang distingtif saja, yakni yang membedakan makna, yang diperbedakan lambangnya.

\section{Fonemik}

Objek penelitian fonemik adalah fonem, yakni bunyi bahasa yang dapat atau berfungsi membedakan makna kata. Jika bunyi itu membedakan makna, maka bunyi tersebut kita sebut fonem, dan jika bunyi itu tidak membedakan makna maka bunyi tersebut bukan fonem.

\section{Identifikasi Fonem}

Untuk mengetahui apakah sebuah bunyi fonem atau bukan, harus mencari sebuah satuan bahasa, biasanya sebuah kata yang mengandung bunyi tersebut, lalu membandingkannya dengan satuan bahasa lain yang mirip dengan satuan bahasa pertama. Kalau ternyata kedua satuan bahasa itu berbeda maknanya berarti bunyi tersebut adalah sebuah fonem, karena dia bisa atau berfungsi membedakan makna kedua satuan bahasa itu.Identitas fonem hanya berlaku dalam satu bahasa tertentu
saja.Fonem dari sebuah bahasa ada yang mempunyai beban fungsional yang tinggi, tetapi ada pula yang rendah.Yang memiliki beban fungsional yang tinggi artinya banyak ditemui pasangan minimal yang mengandung fonem tersebut.

\section{PENUTUP}

Berdasarkan hasil yang dianalisis di atas dapat disimpulkan terdapat pelepasan bunyi fonem yang tidak sesuai kaidah fonologi. Terdapat distribusi bunyi fonem [R] tidak sesuai kaidah bahasa indonesia terdapat di awal kata, di tengah kata dan di akhir kata. Hal ini disebabkan artikulasi siswa belum sempurna untuk menghasilkan bunyi bahasa. Bunyibunyi dental dan bunyi labial belum tepat diucapkan alat-alat ucap.

\section{DAFTAR PUSTAKA}

Chaer, Abdul. (2007). Linguistik Umum. Jakarta: Rineka Cipta.

Chaer, Abdul. (2013) Fonologi Bahasa Indonesia. Jakarta: Rineka Cipta.

Chaer, Abdul. (2009). Fonologi Bahasa Indonesia. Jakarta: Rineka Cipta.

Chaer, Abdul dan Leonie Agustina. (2010). Sosiolinguistik Perkenalan Awal. Jakarta: Rineka Cipta

Chaer, Abdul. 2015. Psikolinguistik. PT. Reneka Cipta: Jakarta

Mar'at,Samsunuwiyati. (2005). Psikolinguistik Suatu Pengantar. Bandung: PT. Refika Aditama.

Muslich, Masnur. (2010). Fonologi Bahasa Indonesia Tinjauan 
Deskriptif Sistem Bunyi Bahasa

Indonesia. Jakarta: Ikrar Mandiriabadi.

Sugiyono, (2010). Metode Penelitian Kuantitatif Kualitatif dan $R \& D$. Bandung: Alfabeta.

Sri Kurnia Hastuti Sebayang. (2018). Jurnal Pena Indonesia. Velume 4 nomor 1, Maret 2018.
file:///C:/Users/SA\%20KRIM/ Downloads/2313-6537-2-

PB\%20(2).pdf

Yulia Eka Salnita dkk. (2019:141). Jurnal Obsesi:Jurnal Pendidikan Anak Usia Dini.Volume 3 issue 1. https://obsesi.or.id/index.php/o bsesi/article/view/156/104 